\title{
Estimasi Arah Tatapan Mata Menggunakan Ensemble Convolutional Neural Network
}

\author{
William Sugiarto \\ Program Studi Magister \\ Teknologi Informasi \\ Sekolah Tinggi Teknik Surabaya \\ williamsugiarto2011@gmail.com
}

\author{
Yosi Kristian \\ Program Studi Magister \\ Teknologi Informasi \\ Sekolah Tinggi Teknik Surabaya \\ yosi@stts.edu
}

\author{
Eka Rahayu Setyaningsih \\ Program Studi Magister \\ Teknologi Informasi \\ Sekolah Tinggi Teknik Surabaya \\ eka@stts.edu
}

\begin{abstract}
Abstrak - Studi arah tatapan mata adalah salah satu masalah dalam bidang computer vision. Pengetahuan akan arah tatapan mata dapat memberikan informasi berharga yang dapat dimanfaatkan untuk berbagai macam keperluan dalam bidang lainnya, khususnya dalam bidang interaksi manusia dengan komputer. Dalam paper ini nantinya akan meneliti arah tatapan mata menggunakan Ensemble Convolutional Neural Network dengan menggunakan dataset CAVE (Columbia Gaze Dataset). Convolutional Neural Netwok (CNN) merupakan sebuah bidang keilmuan dalam bidang machine learning yang berkembang cukup pesat khususnya untuk mengklasifikasi citra. Nantinya, paper ini akan menganalisa dan membandingkan hasil F1 score dan weighted kappa (w-kappa) score serta error dari klasifikasi dengan menggunakan 3, 9, dan 21 kelas. Dengan samasama menggunakan kanal RGB sebagai gambar input, maka dapat dibandingkan dan disimpulkan bahwa dengan menggunakan metode Ensemble Convolutional Neural Network dengan koefisien 1 untuk mata kiri, 1 untuk mata kanan, dan 3 untuk kedua mata untuk klasifikasi dengan 3 dan 9 kelas, serta dengan koefisien 1 untuk mata kiri, 1 untuk mata kanan, dan 5 untuk kedua mata untuk klasifikasi dengan 21 kelas dapat menghasilkan hasil F1 score dan w-kappa yang lebih baik, serta tingkat error yang lebih rendah daripada menggunakan koefisien dengan nilai lainnya.

Kata Kunci: Convolutional Neural Network, Eye Gaze, Gaze Estimation.
\end{abstract}

\section{PENDAHULUAN}

Mata merupakan fitur untuk berkomunikasi dengan tampilan antarmuka yang memiliki peran yang sangat vital. Perhatian seseorang dapat terlihat dari arah tatapan matanya. Mata dan pergerakannya dapat menunjukkan perhatian seseorang dan memiliki peran yang penting dalam mengkomunikasikan suatu informasi sosial maupun emosional [1].

Penelitian tentang pelacakan arah tatapan mata hingga saat ini masih berfokus pada menginterpretasikan posisi mata pada layar secara lebih akurat. Latar belakang dari penelitian yang dilakukan adalah sebagai studi kognitif yang menggunakan mata sebagai kontrol input. Sedangkan tujuan dari penelitian yang dilakukan adalah sebagai alat bantu teknologi (assistive technology) yang berfungsi sebagai alat input yang dapat digunakan pada bidang interaksi manusia dengan komputer, user experience, sosiologi, edukasi, marketing, dalam bidang perindustrian, dan juga bidang-bidang lainnya yang dapat membantu para penyandang disabilitas.

Ada beberapa macam pendekatan yang dapat digunakan untuk menentukan arah tatapan mata. Pada penelitian ini akan menggunakan metode pendekatan berbasis CNN (Convolutional Neural Network). CNN merupakan metode yang terbilang masih relatif baru dan diharapkan dapat memperoleh tingkat kinerja yang jauh lebih baik dibandingkan metode-metode sebelumnya. CNN yang merupakan kategori dari neural network ini terbukti sangat baik dalam hal klasifikasi citra. CNN mempunyai layer untuk convolutional dan pooling, yang dimana MLP (Multilayer Perceptron) tidak memilikinya.

Convolutional Neural Network pertama kali dikembangkan oleh seorang peneliti bernama Kunihiko Fukushima dari NHK Broadcasting Science Research Laboratories, Kinuta, Setagaya, Tokyo, Jepang dengan nama NeoCognitron [2]. Convolution Neural Network bermula dari Yann LeCun dan teman-temannya berhasil melakukan klasifikasi citra kode zip menggunakan kasus khusus dari Feed Forward Neural Network Pada tahun 1989 [3]. Mulai pada tahun 2012, dimana perangkat keras Graphical Processing Unit (GPU) berkembang, DNN juga ikut berkembang dan bahkan sebuah CNN dapat melakukan pengenalan citra dengan akurasi yang sangat baik dan dapat menyaingi manusia pada dataset tertentu [4].

\section{PENELITIAN TERKAIT}

Ada beberapa jenis pendekatan pelacakan arah tatapan mata. Ada pendekatan pelacakan arah tatapan mata yang berbasis fitur [5]-[9] dan juga ada yang berbasis tampilan [10] - [11] dan kedua jenis tersebut merupakan metode yang sudah lama dan sudah digantikan dengan menggunakan metode berbasis CNN. Kedua pendekatan tersebut pada umumnya memerlukan perangkat keras yang cukup mahal dan tidak praktis. Berbeda dengan menggunakan pendekatan berbasis 
CNN yang pada umumnya hanya memerlukan sebuah web camera.

Telah ada beberapa karya terkait yang meneliti arah tatapan mata dengan menggunakan metode $\mathrm{CNN}$, salah satunya adalah [12]. Pada paper tersebut menggunakan CNN untuk mengelolah mata kanan dan mata kiri secara independen dan membandingkan hasil recognition rate antara 3 dan 7 kelas. Pada penelitian tersebut, dua jaringan CNN dilatih secara independen untuk mata kanan dan mata kiri seperti yang ditunjukan pada Gambar 1 dimana kelasnya merupakan hasil maksimal dari rata-rata hasil CNN mata kanan dan mata kiri. Penelitian tersebut meneliti untuk arah tatapan mata tiga dan tujuh kelas. Penelitian tersebut dilakukan dengan dua metode yang berbeda, yaitu menggunakan ERT (Ensemble of Randomized Tree) [13] dan menggunakan geometric (ROI).

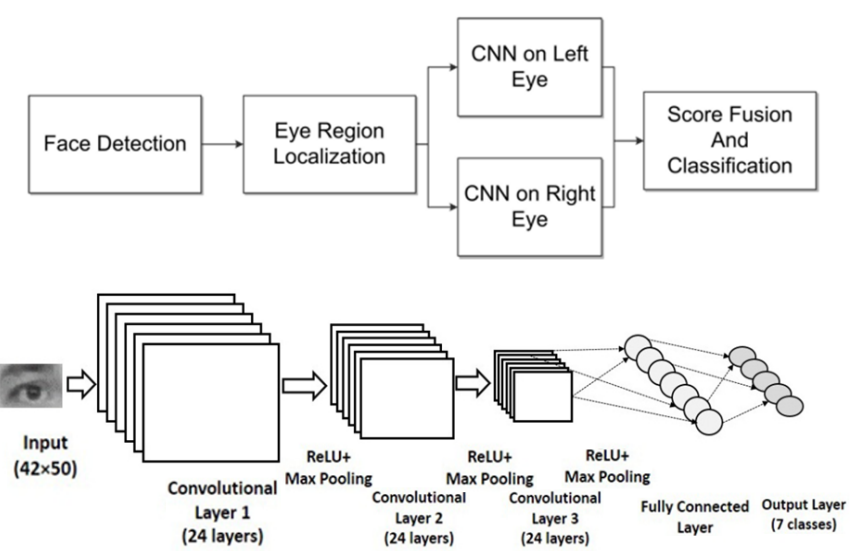

Gambar 1. Skema dan Arsitektur yang Digunakan pada

"Real-time Eye Gaze Direction Classification Using Convolutional Neural Network" [12].

Ada juga penelitian yang meneliti arah tatapan mata ini untuk layar mobile phone maupun tablet [14]. Menggunakan Gaze capture sebagai pengumpul data dan iTracker sebagai deep convolutional neural network untuk memprediksi arah tatapan mata seperti pada Gambar 2. Skema dan arsitektur yang dipakai digambarkan pada Gambar 3.

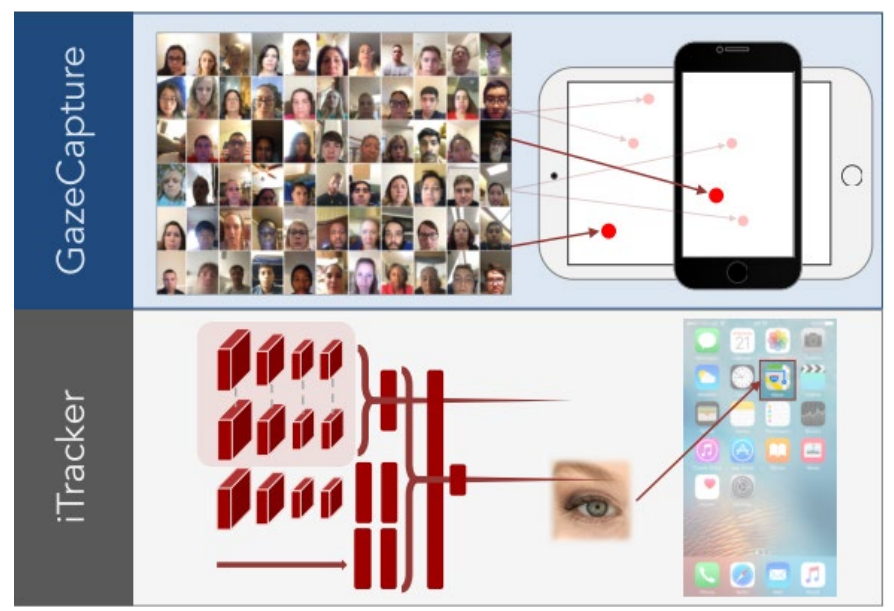

Gambar 2. Gaze Capture yang Digunakan [14].

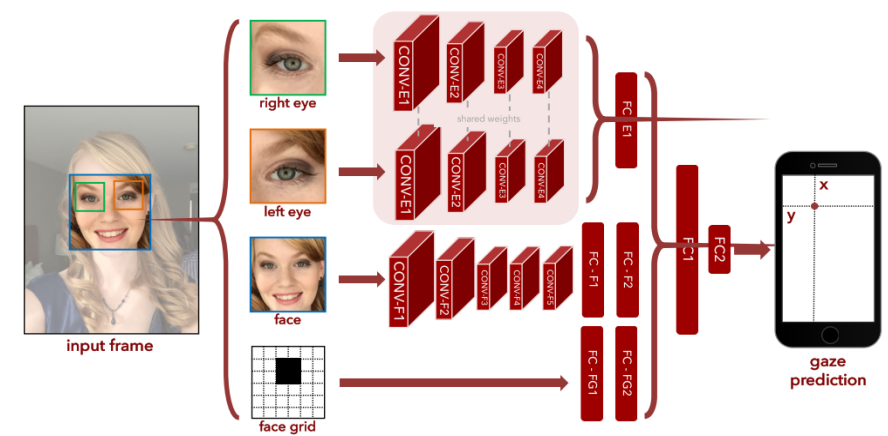

Gambar 3. Skema dan Arsitektur yang Digunakan pada "Eye Tracking for Everyone" [14].

\section{METODE PENELITIAN}

Pada penelitian ini, dataset yang digunakan bersumber dari Columbia Gaze Dataset (CAVE) [15]. Dataset ini berisi 5.880 gambar dengan total 56 subyek (32 subyek pria dan 24 subyek wanita) dengan rentang usia 18 hingga 36 tahun dengan resolusi gambar sebesar 5.184 x 3.456 .

Untuk setiap subyek, diambil gambar dengan lima horizontal head pose $\left(0^{\circ}, \pm 15^{\circ}, \pm 30^{\circ}\right)$ dengan tujuh arah tatapan secara horisontal $\left(0^{\circ}, \pm 5^{\circ}, \pm 10^{\circ}, \pm 15^{\circ}\right)$ dan tiga arah tatapan secara vertikal $\left(0^{\circ}, \pm 10^{\circ}\right)$.

Dataset ini menyuguhkan gambar yang sangat variatif, dimana ada yang menggunakan kacamata maupun tanpa kacamata. Dalam dataset ini juga terdiri dari berbagai macam warna kulit dan memiliki rentang usia antara 18 hingga 36 tahun. Gambar 4 merupakan salah satu contoh dataset-nya.

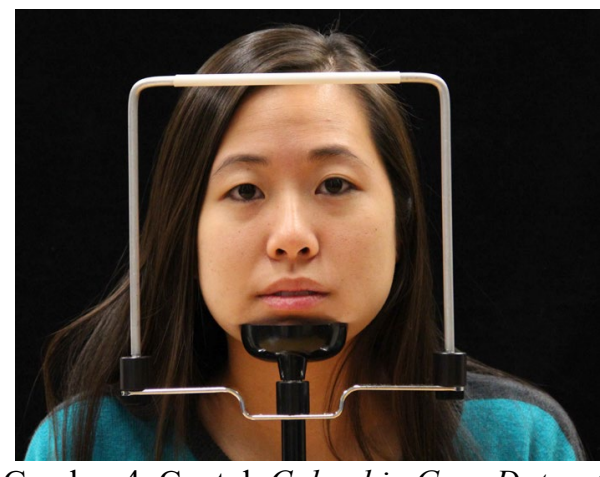

Gambar 4. Contoh Columbia Gaze Dataset.

Sebesar 20\% dari dataset akan digunakan sebagai test set dan $80 \%$ sisanya akan digunakan sebagai train set. Metode untuk train dan test split menggunakan seen respondent test set seperti pada Gambar 5.

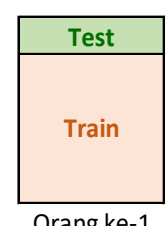

Orang ke-1

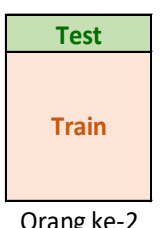

Orang ke-2

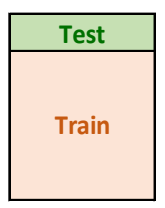

Orang ke-54

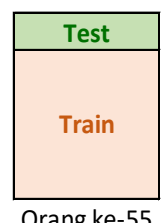

Orang ke-55

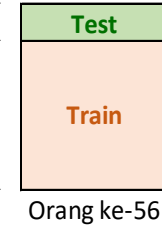

Orang ke-56 
Berikut ini adalah skema yang akan digunakan dalam penelitian ini. Proses awal yang dilakukan adalah dengan memanipulasi gambar asli dengan menggunakan gamma correction sebesar 0,75 . Kemudian memecah atau memotong gambar dataset kedalam tiga bagian terlebih dahulu, yaitu mata kanan, mata kiri, dan kedua mata. Untuk pemotongannya dilakukan dengan melakukan facial landmark detection [16]-[17] untuk mengambil titik-titik pada area mata kiri dan mata kanan. Untuk mata kanan dan kiri diambil secara oval dan memiliki latar belakang berwarna putih seperti yang dicontohkan pada Gambar 6. Dengan menggunakan metode tersebut, dari 5.880 gambar hanya 5.833 gambar yang dapat diproses dan sisanya diabaikan.

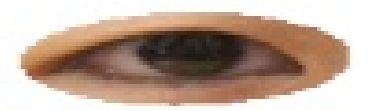

(a)

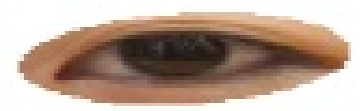

(b)

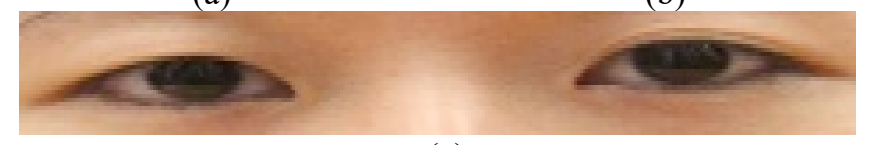

(c)

Gambar 6. Hasil Eye Region Localization untuk (a) Mata Kiri, (b) Mata Kanan, (c) Kedua Mata.

Adapun kaidah untuk menentukan pembagian kelas berdasarkan sudut arah tatapan mata sesuai dengan yang tertera pada Gambar 7.

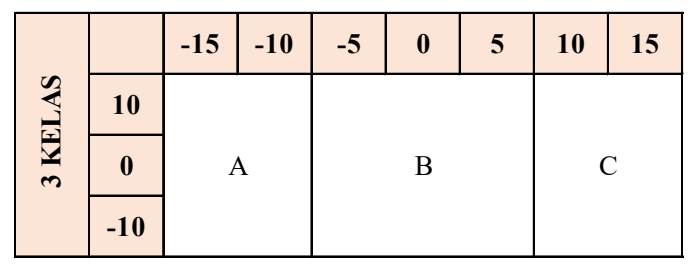

\begin{tabular}{|c|c|c|c|c|c|c|c|c|}
\hline \multirow{4}{*}{$\frac{a}{\frac{1}{3}}$} & & -15 & -10 & -5 & 0 & 5 & 10 & 15 \\
\hline & 10 & \multicolumn{2}{|c|}{ A } & \multicolumn{3}{|c|}{ B } & \multicolumn{2}{|c|}{ C } \\
\hline & 0 & \multicolumn{2}{|c|}{ D } & \multicolumn{3}{|c|}{ E } & \multicolumn{2}{|c|}{$\mathrm{F}$} \\
\hline & -10 & \multicolumn{2}{|c|}{$\mathrm{G}$} & \multicolumn{3}{|c|}{$\mathrm{H}$} & \multicolumn{2}{|c|}{ I } \\
\hline
\end{tabular}

\begin{tabular}{|c|c|c|c|c|c|c|c|c|}
\hline \multirow{2}{*}{$\approx$} & $\mathbf{1 0}$ & $\mathrm{A}$ & $\mathrm{B}$ & $\mathrm{C}$ & $\mathrm{D}$ & $\mathrm{E}$ & $\mathrm{F}$ & $\mathrm{G}$ \\
\cline { 2 - 9 } & $\mathbf{0}$ & $\mathrm{H}$ & $\mathrm{I}$ & $\mathrm{J}$ & $\mathrm{K}$ & $\mathrm{L}$ & $\mathrm{M}$ & $\mathrm{N}$ \\
\cline { 2 - 9 } & $\mathbf{- 1 0}$ & $\mathrm{O}$ & $\mathrm{P}$ & $\mathrm{Q}$ & $\mathrm{R}$ & $\mathrm{S}$ & $\mathrm{T}$ & $\mathrm{U}$ \\
\hline
\end{tabular}

Gambar 7. Pembagian Nama Kelas Berdasarkan Derajat Sudut Tatapan.

Proses CNN akan dilakukan sebanyak 500 epoch pada masing-masing gambar secara independen. Persamaan yang digunakan untuk menghitung score akhir yaitu: score $=\left(\frac{L \text { Score } x W L+\mathrm{R} \text { score } x W R+\mathrm{B} \text { score } x W B}{\mathrm{WL}+\mathrm{WR}+\mathrm{WB}}\right)$

Score L merupakan hasil dari perhitungan softmax untuk mata kiri, score R untuk mata kanan, dan score B untuk kedua mata. Koefisien untuk mata kiri dilabelkan dengan WL, dan untuk mata kanan dilabelkan dengan WR, serta untuk kedua mata dilabelkan dengan WB. Kelas yang dipilih akan ditentukan dengan probabilitas maksimum yaitu:

class $=\arg \max ($ score $)$

Pada Gambar 8, menunjukan skema rangkaian kerja yang akan digunakan pada penelitian ini. Pada gambar ini juga dapat menjelaskan dengan lebih mudah maksud dari persamaan 1 dan 2 .

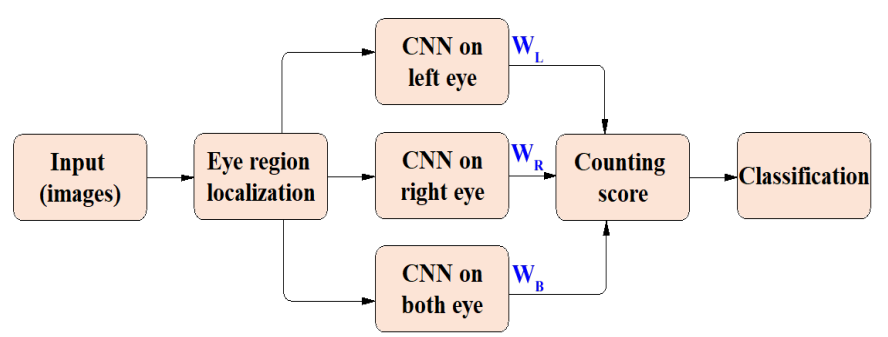

Gambar 8. Skema yang Digunakan

Dalam CNN terdapat beberapa macam fungsi aktivasi yang dapat digunakan diantaranya adalah Rectified Linear Unit (ReLU) dan softmax. ReLU merupakan fungsi aktivasi yang akan menghasilkan nilai nol apabila $\mathrm{x}<0$ dan kemudian linier dengan kemiringan 1 ketika $\mathrm{x}>0$

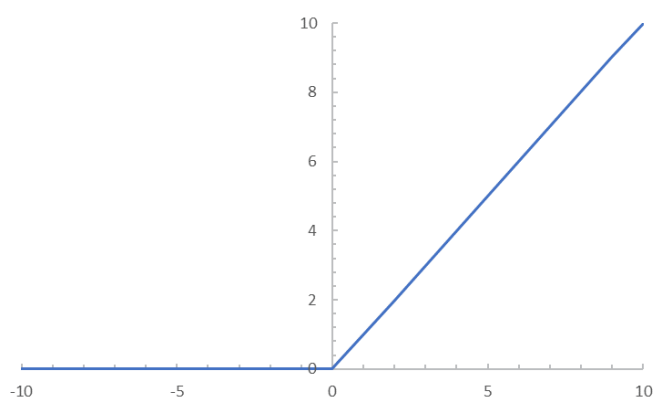

Gambar 9. Fungsi Aktivasi Rectified Linear Unit (ReLU).

Aktivasi softmax dipilih karena output dari lapisan terakhir pada sebuah jaringan saraf akan diubah menjadi distribusi probabilitas dasarnya dan memiliki rentang antara 0 hingga 1 , dan juga jumlah semua probabilitasnya adalah satu. Adapun persamaan untuk menghitung softmax yaitu:

$$
f_{i}(\vec{x})=\frac{e^{x_{i}}}{\sum_{j=1}^{k} e^{x_{j}}} \quad \text { for } i=1,2,3, \ldots, k \ldots
$$


Pada penelitian ini menggunakan Adam Optimizer [18]. Nama Adam berasal dari adaptive moment estimation. Adam adalah algoritma optimasi yang dapat digunakan sebagai pengganti prosedur stochastic gradient descent klasik untuk memperbaharui bobot jaringan yang berbasis pada data pelatihan.

Untuk proses CNN pada mata kiri dan mata kanan akan menggunakan arsitektur seperti tertera pada Gambar 10, yang dimana convolutional layer tahap pertama menggunakan 24 filter dengan dimensi $7 \times 7$ dan diikuti dengan rectified linear unit serta 2 x 2 max pooling layer. Sedangkan untuk convolutional layer tahap kedua dan ketiga, keduanya menggunakan 24 filter dengan dimensi 5 x 5 dan juga $3 \times 3$, serta proses ReLU dan max pooling yang sama seperti pada tahap sebelumnya.

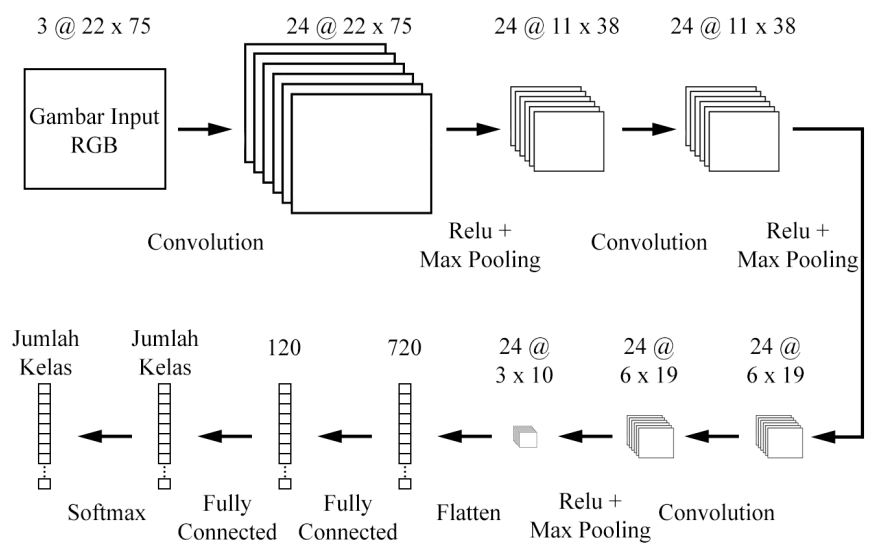

Gambar 10. Arsitektur CNN untuk Mata Kanan dan Mata Kiri.

Untuk proses CNN dengan menggunakan kedua mata akan menggunakan arsitektur yang berbeda. Arsitektur yang digunakan untuk CNN dengan kedua mata ditunjukkan pada Gambar 11 dengan dimensi filter yang digunakan yaitu $24 @$ $7 x 7,28 @ 7 x 7,32 @ 5 x$ 5, dan36@3x3 dan masingmasingnya dilakukan proses ReLU dan max pooling yang sama seperti pada proses CNN untuk mata kanan dan mata kiri.

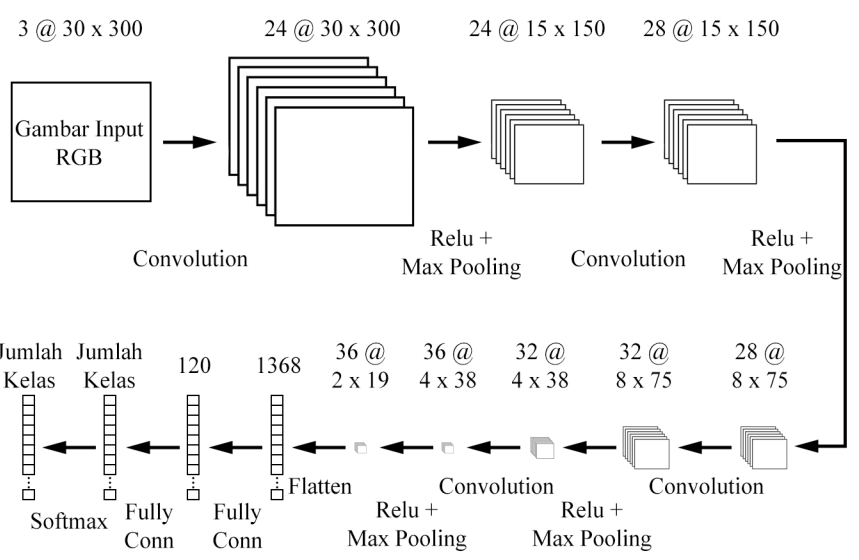

Gambar 11. Arsitektur CNN untuk Kedua Mata.
Gambar yang digunakan sebagai input merupakan gambar dengan 3 kanal (gambar RGB). Hasil outputnya sejumlah banyaknya kelas itu sendiri dan merupakan hasil softmax dari 3, 9, atau 21 kelas tergantung dari apa yang sedang diujicobakan.

Untuk menghitung kinerja sistem dapat menggunakan F1 score. F1-score adalah ukuran suatu kinerja yang mempertimbangkan presisi $\mathrm{p}$ maupun recall $\mathrm{r}$ untuk menghitung skor. Nilai F1-score memiliki nilai terbaiknya yaitu 1 dan terburuk adalah 0 .

$\mathrm{F}=2 \frac{\mathrm{PR}}{\mathrm{P}+\mathrm{R}}$

Weighted kappa (w-kappa) juga dapat digunakan untuk mengukur kinerja sistem. Dengan menggunakan w-kappa, maka jarak jauh dekatnya error akan mempengaruhi nilai yang dihasilkan. Khusus untuk penelitian ini, persamaan wkappa yang digunakan sedikit diubah agar rentang nilai yang dihasilkan berapa pada 0 untuk nilai terendahnya, dan 1 untuk nilai tertingginya. Persamaan w-kappa yang digunakan adalah sebagai berikut:

$$
\kappa_{w}=\max \left(0,1-\frac{\sum_{i, j} w_{i j} p_{i j}}{\sum_{i, j} w_{i j} e_{i j}}\right)
$$

Dimana untuk menetapkan nilai koefisiennya, maka digunakan teorema pythagoras. Sebagai contoh kasus, jika kelas yang sebenarnya adalah kelas " $A$ " dan ditebak sebagai kelas "P" pada klasifikasi dengan menggunakan 21 kelas, maka akan memiliki nilai koefisien sebesar 2,236 seperti pada Gambar 12.

\begin{tabular}{|c|c|c|c|c|c|c|}
\hline A & B & C & D & $\mathbf{E}$ & $\mathbf{F}$ & G \\
\hline $\begin{array}{r}\mathbf{H} \\
2\end{array}$ & $\begin{array}{c}2,236 \\
\mathbf{I}\end{array}$ & $\mathbf{J}$ & K & L & $\mathbf{M}$ & $\mathbf{N}$ \\
\hline 0 & $\frac{1}{1 P}$ & $\mathbf{Q}$ & $\mathbf{R}$ & $S$ & $\mathbf{T}$ & $U$ \\
\hline
\end{tabular}

Gambar 12. Perhitungan Koefisien W-Kappa untuk Klasifikasi dengan 21 Kelas.

Hasil perhitungan tersebut akan dibulatkan menjadi tiga angka dibelakang koma. Pada gambar 13, telah dicontohkan nilai koefisien untuk klasifikasi dengan menggunakan 9 kelas. Sebagai catatan tambahan, bahwa hasil tabel tersebut simetris pada diagonalnya.

Sedangkan error yang dihasilkan memiliki nilai dengan rentang mulai dari 0 hingga 1 . Hasil bernilai 0 apabila semua tebakannya benar, dan bernilai 1 apabila semua tebakannya salah. Untuk menghitung error yang dihasilkan, dapat digunakan persamaan sebagai berikut:

Error $=\frac{\text { number of images }- \text { number of correct predictions }}{\text { number of images }}$ 


\begin{tabular}{|c|c|c|c|c|c|c|c|c|}
\hline A & B & C & D & $E$ & $F$ & G & $\mathrm{H}$ & 1 \\
\hline 0 & 1 & 2 & 1 & 1,414 & 2,236 & 2 & 2,236 & 2,828 \\
\hline 1 & 0 & 1 & 1,414 & 1 & 1,414 & 2,236 & 2 & 2,236 \\
\hline 2 & 1 & 0 & 2,236 & 1,414 & 1 & 2,828 & 2,236 & 2 \\
\hline 1 & 1,414 & 2,236 & 0 & 1 & 2 & 1 & 1,414 & 2,236 \\
\hline 1,414 & 1 & 1,414 & 1 & 0 & 1 & 1,414 & 1 & 1,414 \\
\hline 2,236 & 1,414 & 1 & 2 & 1 & 0 & 2,236 & 1,414 & 1 \\
\hline 2 & 2,236 & 2,828 & 1 & 1,414 & 2,236 & 0 & 1 & 2 \\
\hline 2,236 & 2 & 2,236 & 1,414 & 1 & 1,414 & 1 & 0 & 1 \\
\hline 2,828 & 2,236 & 2 & 2,236 & 1,414 & 1 & 2 & 1 & 0 \\
\hline
\end{tabular}

Gambar 13. Koefisien W-Kappa untuk Klasifikasi dengan Sembilan Kelas.

\section{UJI COBA}

Uji coba ini dilakukan dengan menggunakan koefisien yang berbeda-beda. Untuk mempermudah penyebutan, maka penamaan koefisien dimulai dari WL, lalu WR, dan WB.
Misalkan koefisien 113 yang berarti koefisien 1 untuk WL (mata kiri), 1 untuk WR (mata kanan), dan 3 untuk WB (kedua mata).

Tabel 1. Hasil Training

\begin{tabular}{|c|c|c|c|c|c|c|c|}
\hline \multirow[b]{2}{*}{ Koefisien } & \multirow{2}{*}{$\begin{array}{c}\text { Metode } \\
\text { Pengukuran }\end{array}$} & \multicolumn{2}{|c|}{3 Kelas } & \multicolumn{2}{|c|}{9 Kelas } & \multicolumn{2}{|c|}{21 Kelas } \\
\hline & & $\begin{array}{c}\text { Hasil } \\
\text { Training } \\
\end{array}$ & $\begin{array}{l}\text { Hasil } \\
\text { Testing }\end{array}$ & $\begin{array}{c}\text { Hasil } \\
\text { Training }\end{array}$ & $\begin{array}{l}\text { Hasil } \\
\text { Testing }\end{array}$ & $\begin{array}{c}\text { Hasil } \\
\text { Training }\end{array}$ & $\begin{array}{l}\text { Hasil } \\
\text { Testing }\end{array}$ \\
\hline \multirow{3}{*}{111} & F1 Score & 1.000 & 0.819 & 0.924 & 0.643 & 0.987 & 0.491 \\
\hline & W-Kappa & 1.000 & 0.766 & 0.929 & 0.630 & 0.990 & 0.729 \\
\hline & Error & 0.000 & 0.185 & 0.080 & 0.387 & 0.013 & 0.507 \\
\hline \multirow{3}{*}{112} & F1 Score & 1.000 & 0.828 & 1.000 & 0.758 & 0.987 & 0.562 \\
\hline & W-Карра & 1.000 & 0.779 & 1.000 & 0.809 & 0.993 & 0.776 \\
\hline & Error & 0.000 & 0.175 & 0.000 & 0.241 & 0.013 & 0.442 \\
\hline \multirow{3}{*}{113} & F1 Score & 1.000 & 0.845 & 1.000 & 0.771 & 0.989 & 0.575 \\
\hline & W-Kappa & 1.000 & 0.799 & 0.999 & 0.819 & 0.994 & 0.778 \\
\hline & Error & 0.000 & 0.156 & 0.000 & 0.230 & 0.011 & 0.424 \\
\hline \multirow{3}{*}{114} & F1 Score & 1.000 & 0.841 & 1.000 & 0.759 & 0.994 & 0.598 \\
\hline & W-Карра & 1.000 & 0.794 & 1.000 & 0.811 & 0.997 & 0.797 \\
\hline & Error & 0.000 & 0.162 & 0.000 & 0.242 & 0.006 & 0.401 \\
\hline \multirow{3}{*}{115} & F1 Score & 1.000 & 0.839 & 1.000 & 0.761 & 0.993 & 0.615 \\
\hline & W-Kappa & 1.000 & 0.793 & 1.000 & 0.812 & 0.996 & 0.809 \\
\hline & Error & 0.000 & 0.164 & 0.000 & 0.241 & 0.007 & 0.386 \\
\hline \multirow{3}{*}{117} & F1 Score & 1.000 & 0.834 & 0.999 & 0.763 & 0.994 & 0.583 \\
\hline & W-Kappa & 1.000 & 0.783 & 0.999 & 0.811 & 0.997 & 0.795 \\
\hline & Error & 0.000 & 0.168 & 0.001 & 0.240 & 0.006 & 0.414 \\
\hline
\end{tabular}
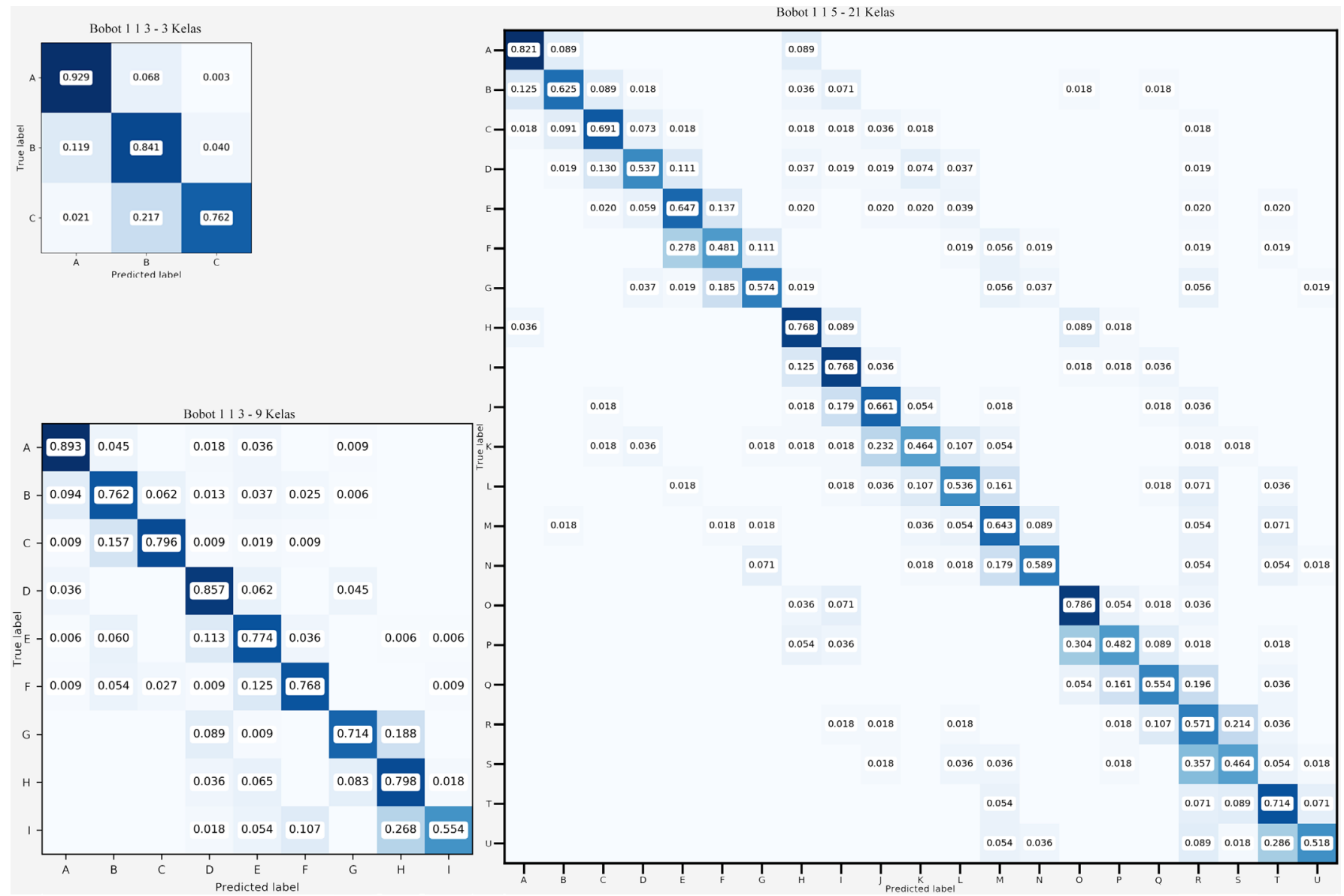

Gambar 14. Arsitektur CNN untuk Kedua Mata. 
Uji coba ini dilakukan dengan menggunakan 6 macam koefisien yang berbeda. Keenam koefisien tersebut adalah 11 $1,112,113,114,115$, dan 117 dan diujicobakan untuk 3, 9, dan 21 kelas. Untuk semua percobaan yang diujikan menggunakan gambar input RGB dan dilakukan training sebanyak 500 epoch dengan ukuran batch sebesar 64 dan learning rate sebesar 1e-4. Kompleksitas perhitungan yang dipakai termasuk cukup kompleks. Dengan menggunakan Core i5-6200U@2.30 GHz (8GB RAM) pada Windows 10 dan Nvidia GeForce 930MX dengan dedicated GPU memory 2GB memerlukan waktu training sekitar 9 hingga 10 jam.

Pada Tabel 1, klasifikasi menggunakan 3 kelas pada koefisien 113 menghasilkan hasil testing paling baik, dimana F1 score mencapai 0,845, w-kappa sebesar 0,799, dan error hanya 0.156 . Hasil untuk klasifikasi 9 kelas yang didapat serupa dengan hasil klasifikasi menggunakan 3 kelas dimana nilai terbaiknya berada pada koefisien 113 dengan F1 score sebesar 0,771, w-kappa sebesar 0,819, dan error hanya 0,23.

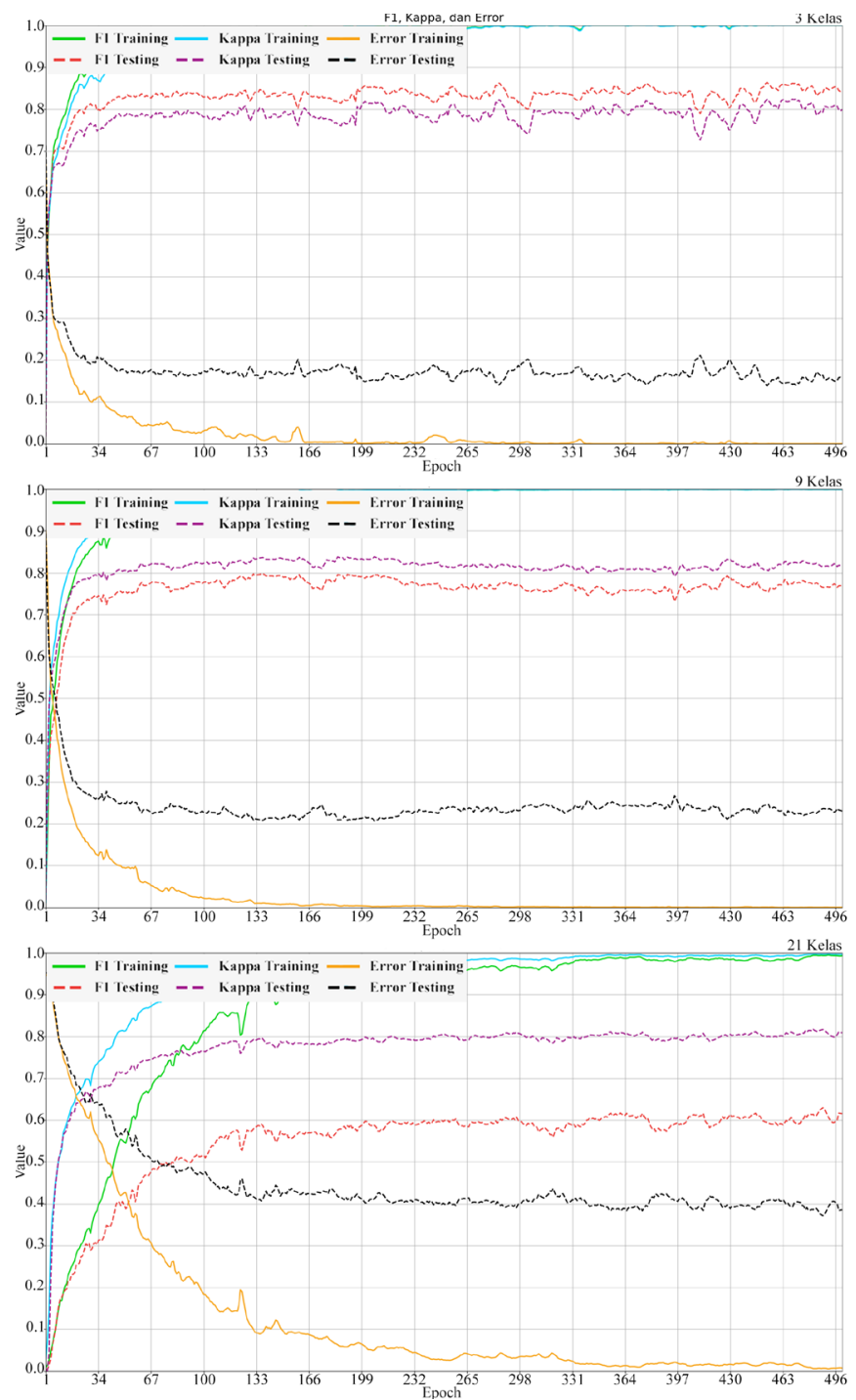

Gambar 15. Grafik Training dan Testing dengan Menggunakan Koefisien Terbaik.
Namun, untuk klasifikasi dengan menggunakan 21 kelas, performa optimalnya didapat pada koefisien 115 dimana F1 score yang dihasilkan yaitu 0,615 , dan w-kappa sebesar 0,809 , serta error yang didapat yaitu 0,386. Pada gambar 14 merupakan hasil confusion matrix dengan menggunakan koefisien terbaik. Dan pada gambar 15 menunjukkan grafik training dan testing dengan mernggunakan koefisien terbaik untuk 3, 9, dan 21 kelas.

Sebagai hasil pembanding, akan digunakan paper yang ditulis oleh A. George bersama dengan A. Routray yang berjudul "Real-time Eye Gaze Direction Classification Using Convolutional Neural Network" [12]. Pada penelitian tersebut dataset yang digunakan adalah Eye Chimera database [19], [20] yang mengandung tujuh kelas EAC (Eye Accessing Cues). Dataset tersebut berisi 40 subyek dengan total 1170 gambar.
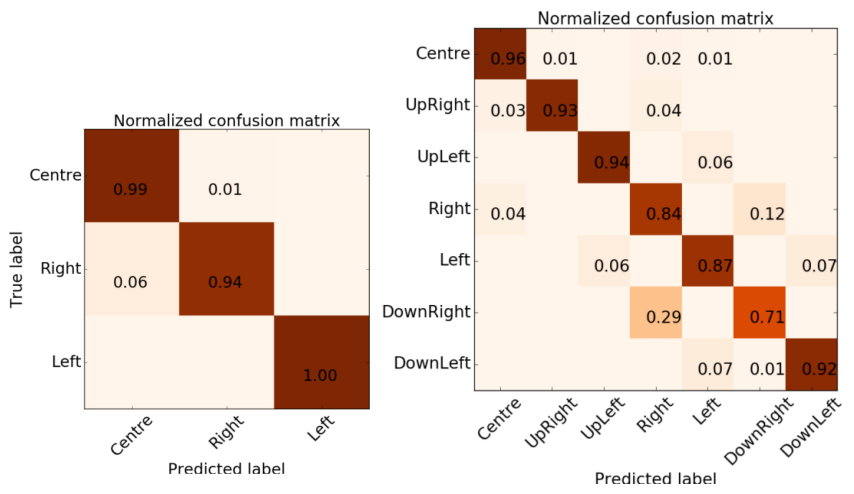

Gambar 16. Normalized Confusion Matrix pada Paper [12].

Pada Gambar 16 merupakan normalized confusion matrix untuk 3 dan 7 kelas pada paper [12]. Agar hasil yang dibandingkan dapat mendekati kemiripan, mekipun dataset yang digunakan berbeda dikarenakan tidak berhasil untuk mendapatkan dataset Eye Chimera database, maka hasil dari percobaan 9 kelas pada penelitian ini akan dikonversi menjadi 7 kelas arah tatapan mata seperti yang ditunjukan pada Gambar 17.

\begin{tabular}{|c|c|c|c|c|c|c|c|}
\hline & -15 & -10 & -5 & $\mathbf{0}$ & 5 & 10 & 15 \\
\hline 10 & \multicolumn{2}{|c|}{ Up Left } & \multirow{3}{*}{\multicolumn{3}{|c|}{ Centre }} & \multicolumn{2}{|c|}{ Up Right } \\
\hline 0 & \multicolumn{2}{|c|}{ Left } & & & & \multicolumn{2}{|c|}{ Right } \\
\hline-10 & \multicolumn{2}{|c|}{ Down Left } & & & & \multicolumn{2}{|c|}{ Down Right } \\
\hline
\end{tabular}

Gambar 17. Konversi Dari 9 Kelas Menjadi 7 Kelas Arah Tatapan Mata.

Tabel 2 merupakan tabel hasil yang dicapai pada 3 dan 7 kelas arah tatapan mata melengkapi tabel perbandingan yang ditulis pada paper [12]. Pada tabel tersebut menunjukkan bahwa hasil yang didapat pada penelitian ini sedikit dibawah penelitian yang dilakukan oleh [12]. Hal itu dimungkinkan karena adanya perbedaan dataset yang digunakan dimana Eye Chimera hanya memiliki 1.170 gambar, sedangkan pada Columbia Gaze Dataset memiliki gambar yang lebih bervariasi dan lebih banyak (pada penelitian ini menggunakan 5.833 gambar). 
Tabel 2. Perbandingan Akurasi

\begin{tabular}{llccc}
\hline $\begin{array}{c}\text { Lokalisasi } \\
\text { Mata }\end{array}$ & $\begin{array}{c}\text { Klasifikasi } \\
\text { Arah Mata }\end{array}$ & $\begin{array}{c}\text { Jumlah } \\
\text { Gambar } \\
\text { Dataset }\end{array}$ & $\begin{array}{c}\mathbf{3} \\
\text { Kelas } \\
\mathbf{( \% )}\end{array}$ & $\begin{array}{c}\mathbf{7} \\
\text { Kelas } \\
\mathbf{( \% )}\end{array}$ \\
\hline BoRMaN [21] & Valenti [22] & 1.170 & 55.73 & 39.83 \\
\hline Zhu [23] & Zhu [23] & 1.170 & 63.01 & 43.29 \\
\hline $\begin{array}{l}\text { Vrânceanu } \\
{[20]}\end{array}$ & $\begin{array}{l}\text { Vrânceanu } \\
{[20]}\end{array}$ & 1.170 & 95.21 & 83.08 \\
\hline $\begin{array}{l}\text { George (ROI) } \\
{[12]}\end{array}$ & George [12] & 1.170 & 85.58 & 97.65 \\
\hline $\begin{array}{l}\text { George (ERT) } \\
{[12]}\end{array}$ & George [12] & 1.170 & 98.32 & 89.81 \\
\hline $\begin{array}{l}\text { Proposed } \\
{[16],[17]}\end{array}$ & Proposed & 5.833 & 84.36 & 79.36 \\
\hline
\end{tabular}

\section{KESIMPULAN DAN SARAN}

Dari hasil uji coba, dengan menggunakan dataset dengan karakteristik seen responden test set dan gambar input RGB, maka diperoleh nilai koefisien yang baik adalah 113 untuk klasifikasi dengan 3 dan 9 kelas, dan 115 untuk klasifikasi dengan 21 kelas. Dengan menggunakan koefisien yang tepat, dapat meningkatkan F1 score maupun w-kappa serta menurunkan error. Akan tetapi koefisien yang tidak pas atau terlalu besar/kecil terutama koefisien pada kedua mata, malah dapat menurunkan peforma.

Terdapat beberapa saran untuk penelitian selanjutnya, yaitu mencoba dengan menggunakan gambar greyscale ataupun dengan gambar input yang memiliki gamma correction yang berbeda dengan paper ini. Serta perlunya mencari nilai koefisien yang lain yang dapat meningkatkan performa yang ada. Bahkan juga dapat merubah arsitektur untuk mata kanan dan kiri, serta arsitektur untuk kedua mata misalnya pada ukuran gambar input, jumlah dan ukuran filter, ataupun memodifikasi layer yang digunakan.

\section{REFERENSI}

[1] Coates, A., Arbor, A., \& Ng, A.Y. (2011). An Analysis of Single-Layer Networks in Unsupervised Feature Learning. Aistats 2011, 15, pp. 215-223. https://doi.org/10.1109/ICDAR.2011.95

[2] Florea, L., \& Vertan, C. (2013). Can Your Eyes Tell Me How You Think? A Gaze Directed Estimation of the Mental Activity. Bmvc2013, pp. 1-11. https://doi.org/10.5244/C.27.60

[3] Fukushima, K. (1980). Neocognitron: A Self-organizing Neural Network Model for a Mechanism of Pattern Recognition Unaffected by Shift in Position. Biological Cybernetics, 36(4), pp. 193-202. https://doi.org/10.1007/BF00344251

[4] George, A., \& Routray, A. (2016). Real-time Eye Gaze Direction Classification Using Convolutional Neural Network.
[5] Kazemi, V., \& Sullivan, J. (2014). One Millisecond Face Alignment with an Ensemble of Regression Trees. Proceedings of the IEEE Computer Society Conference on Computer Vision and Pattern Recognition, pp. 18671874. https://doi.org/10.1109/CVPR.2014.241

[6] Kingma, D.P., \& Ba, J. (2014). Adam: A Method for Stochastic Optimization, pp. 1-15. https://doi.org/10.1145/1830483.1830503

[7] Krafka, K., Khosla, A., \& Kellnhofer, P. (n.d.). Eye Tracking for Everyone.

[8] Kristian, Y., Takahashi, H., Purnama, I.K.E., Yoshimoto, K., Setiawan, E.I., Hanindito, E., \& Purnomo, M.H. (2017). A Novel Approach on Infant Facial Pain Classification Using Multi Stage Classifier and Geometrical-textural Features Combination. IAENG International Journal of Computer Science, 44(1), pp. 112-121.

[9] Meyer, A., Böhme, M., Martinetz, T., \& Barth, E. (2006). A Single-Camera Remote Eye Tracker (pp. 208-211). Berlin: Springer, Heidelberg. https://doi.org/10.1007/ 11768029_25

[10] Morimoto, C.H., Amir, A., \& Flickner, M. (n.d.). Detecting Eye Position and Gaze from a Single Camera and 2 Light Sources. In Object Recognition Supported by User Interaction for Service Robots. IEEE Comput. Soc., Vol. 4, pp. 314-317. https://doi.org/10.1109/ ICPR.2002.1047459

[11] Setyati, E., Kristian, Y., Pranoto, Y.M., \& Alexandre, D. (2013). Augmented Reality 3D Eyeglasses Frame Simulator Using Active Shape Model and Real Time Face Tracking. 2013 Eleventh International Conference on ICT and Knowledge Engineering, pp. 1-5. https://doi.org/10.1109/ICTKE.2013.6756272

[12] Sheela, S.V, Vijaya, P.A., \& College, B.M.S. (2011). An Appearance Based Method for Eye Gaze Tracking, 7(8), pp. 1194-1203.

[13] Shih, S.W., \& Liu, J. (2004). A Novel Approach to 3-D Gaze Tracking Using Stereo Cameras. IEEE Transactions on Systems, Man and Cybernetics, Part B (Cybernetics), 34(1), pp. 234-245. https://doi.org/ 10.1109/TSMCB.2003.811128

[14] Smith, B.A., Yin, Q., Feiner, S.K., \& Nayar, S. K. (2013). Gaze Locking: Passive Eye Contact Detection for Human-Object Interaction. ACM Symposium on User Interface Software and Technology, pp. 271-280. https://doi.org/10.1145/2501988.2501994

[15] Stephenson, G.M., \& Rutter, D.R. (1970). Eye-Contact, Distance and Affiliation. British Journal of Psychology, 61(3), 385-393. https://doi.org/10.1111/j.20448295.1970.tb01257.x

[16] Valenti, R., \& Gevers, T. (2008). Accurate Eye Center Location and Tracking Using Isophote Curvature. 26th IEEE Conference on Computer Vision and Pattern Recognition, CVPR. https://doi.org/10.1109/ CVPR.2008.4587529

[17] Valstar, M., Martinez, B., Binefa, X., \& Pantic, M. (2010). Facial Point Detection Using Boosted Regression and Graph Models. Proceedings of the IEEE Computer 
Society Conference on Computer Vision and Pattern Recognition, pp. 2729-2736. https://doi.org/10.1109/ CVPR.2010.5539996

[18] Villanueva, A., Cabeza, R., \& Porta, S. (2006). Eye Tracking: Pupil Orientation Geometrical Modeling. Image and Vision Computing, 24(7), pp. 663-679. https://doi.org/10.1016/j.imavis.2005.06.001

[19] Villanueva, A., Cabeza, R., \& Porta, S. (2007). Gaze Tracking System Model Based On Physical Parameters. International Journal of Pattern Recognition and Artificial Intelligence, 21(05), pp. 855-877. https://doi.org/10.1142/S0218001407005697

[20] Vrânceanu, R., Florea, C., Florea, L., \& Vertan, C. (2013). NLP EAC recognition by component separation in the eye region. Lecture Notes in Computer Science
(Including Subseries Lecture Notes in Artificial Intelligence and Lecture Notes in Bioinformatics), 8048 LNCS(PART 2), pp. 225-232. https://doi.org/10.1007/ 978-3-642-40246-3 28

[21] LeCun, Y. (1990). Handwritten Digit Recognition with a Back-Propagation Network.

[22]Zhang, X., Yusuke, Y., Fritz, M., \& Bulling, A. (2015). Appearance-Based Gaze Estimation in the Wild, 1-10.

[23]Zhu, X., \& Ramanan, D. (2012). Face Detection, Pose Estimation, and Landmark Localization in the Wild. Proceedings of the IEEE Computer Society Conference on Computer Vision and Pattern Recognition, pp. 28792886. https://doi.org/10.1109/CVPR.2012.6248014 